\title{
Symptoms of chronic rhinosinusitis with and without nasal polyps
}

\author{
Dirk Dietz de Loos $^{1 *}$, Claire Hopkins ${ }^{2}$, Wytske Fokkens ${ }^{1}$ \\ From 9th Symposium of Experimental Rhinology and Immunology of the Nose (SERIN 2013) \\ Leuven, Belgium. 21-23 March 2013
}

\section{Background}

According to EPOS, chronic rhinosinusitis with and without nasal polyps diagnoses are defined by clinical criteria, supported with endoscopy. We want to know if it is possible to make an accurate distinction between patients with and without nasal polyps based on a limited number of clinical criteria, collected by health-related quality of life questionnaires. A validated instrument that can differentiate patients with chronic rhinosinusitis with and without nasal polyps could be used in epidemiologic research.

\section{Methods}

We collected RSOM-31 (Rhinosinusitis Outcome Measurement) questionnaires from CRS patients with and without nasal polyps and compared mean total RSOM31 scores, mean domain scores, mean symptoms scores, and percentages of patients reporting symptoms per diagnosis based on endoscopy and CT scan. Furthermore a prediction model was obtained by multivariable regression analysis, to define individual risk for nasal polyps in daily practice.

\section{Results}

RSOM-31 Questionnaires were collected from 234 patients. Although total RSOM-31 score was similar and symptomatology considerably overlapping, patients with CRSwNP (with nasal polyps) scored significantly higher and more often on nasal symptoms as 'Rhinorrhoea' and 'Decreased sense of taste or smell'. Patients with CRSsNP (without nasal polyps) significantly scored more often and higher on 'facial pain' and 'ear pain'. A prediction model containing patient characteristics and the RSOM-31 items 'Rhinorrhoea', 'Decreased sense of taste or smell', 'facial

\footnotetext{
${ }^{1}$ Academic Medical Centre, Otorhinolaryngology, Amsterdam, the Netherlands

Full list of author information is available at the end of the article
}

pain', 'ear pain' and 'Inconvenience of always having to carry tissues around' gives a sensitivity of $81 \%$ and specificity of $61 \%$ on the outcome 'nasal polyps'.

\section{Conclusion}

Although there are significant differences scored on several symptoms, there is considerable overlap of many symptoms and it remains difficult to distinguish between CRSWNP and CRSsNP based on clinical impression alone. We constructed a prediction model that makes a distinction between patients with and without nasal polyps with a certain sensitivity and specificity. This instrument could be used for epidemiologic research on chronic rhinosinusitis.

\section{Author details \\ ${ }^{1}$ Academic Medical Centre, Otorhinolaryngology, Amsterdam, the Netherlands. 'uy's Hospital, Otorhinolaryngology, London, UK.}

Published: 16 July 2013

doi:10.1186/2045-7022-3-S2-O2

Cite this article as: Dietz de Loos et al: Symptoms of chronic

rhinosinusitis with and without nasal polyps. Clinical and Translational Allergy 2013 3(Suppl 2):O2.

Submit your next manuscript to BioMed Central and take full advantage of:

- Convenient online submission

- Thorough peer review

- No space constraints or color figure charges

- Immediate publication on acceptance

- Inclusion in PubMed, CAS, Scopus and Google Scholar

- Research which is freely available for redistribution
C Biomed Central

(c) 2013 Dietz de Loos et al; licensee BioMed Central Ltd. This is an Open Access article distributed under the terms of the Creative Commons Attribution License (http://creativecommons.org/licenses/by/2.0), which permits unrestricted use, distribution, and reproduction in any medium, provided the original work is properly cited. 